\title{
感覚融合に関する研究 (I)
}

\section{— 刺激面積, 刺激時間の融合時間に及ぼす影響 —— \\ *}

\author{
東京教育大学心理学研究室
}

\section{小保内虎夫 須 藤 容 治**}

感覚や知覚や観念の成立にとつて, fusion のメカニズ ムがきわめて重要な役割を演じているにもかかわらず, これに関して立大つた考察のなされることがはなはだ少 ない。心理学の教科書でも，これをるとめて述べたもの としては小保内*** のものがあるに過ぎないといつても 過言でない。もちろん考察が少ないといつて定性的な研 究ならばなくはない。たとえば Titchener 門下によつて 特こなわれた感覚融合の内省的研究がそれである。また 定量的な研究も存在しないことはない。たとえば混色, 昔融合, 感覚融合頻度の測定などがこれである。、しかし Titchener 風の研究では研究の心理学的意義が十分に理 解されているものの, その方法が内省飞偏し，心理学の 現代的性格に灭けるうらみがある。これに反して混色や c.f.f. の研究は, 測定の正確さに和いて科学性を誇りう るが，その心理学的意義が顧られないますに放置されて いる。それゆえ, この2つの研究領域は現代心理学の観 点から見直され, 考光直される必要があり, むしこれが なされるならね゙，心理学にとつて大きな寄与となるであ ろう。

本研究は, この観点から感覚融合に関して数量的な規 則性を確立しょうとしたものである。このため感覚融合 時間の問題をとり上げた。現在, 感覚融合時間を測定す るためにはフリッカー法が採られているが，しかしこの 方法では刺激が反復呈示されて興舊の集積が生ずるため その測定值は正確に感覚の持続時間を示すとはいえな い。われわれは反復呈示法をとらず，2つの剌激を継時 的に与える方法を用いて，この問題を研究しょうとする むのである。この方法は古く, 時間間の测定用いられ たものと同じであるが，ただ近代的な装置を用いるとこ ろが埋なる。古心研究では装置が不完全であり，また判 断基淮が明瞭を欠くため測定值が区々として 信頼できな

* Studies on sensory fusion (I)-The effect of area and duration upon fusion time-

** T. Obonai and Y. Suto (Department of Psychology, Tokyo University of Education)

*** 小保内著 心理学一人間科学の基礎一1955, 中 山畫店, $92 \mathrm{ff}$,
い。われわれはこれをもつと正確に測定しようと目指し 以下のような害験を招こなつた。

\section{I 同一箇所に呈示される 2 刺激の融合}

\section{実 験 1}

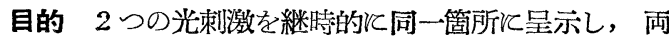
者が融合して見えるための両者間の最大時間間隔，执よ び両者が分離して見えるための最小時間間隔を求め，こ れらの值が刺激の面積と呈示時間の変化汒よつていかて 変るかを明らかにする。

実験条件と実験方法 暗室中で 1 辺 2.5，5，10，20， $40 \mathrm{~mm}$ の 種の正方形の光刺激を被験者の眼の高さで呈 示する。刺激用の光源にはネオン登を用い， 2 刺激の呈 示時間はつね等しく, 100, 200, 400 $\mathrm{msec} の 3$ 種とす るが，光源の点隇は水沢式時間知覚器(1) 飞よる。使用 された装置の誤差は，8回の実測の結果，100 mec rつ いて平均偏差 $0.6 \mathrm{msec}$ である。各刺激呈示間には約 20 秒 の休止を挿入し，残像が現われた場合は，その消失後少 なくも10秒を和いて次の刺激呈示を特こなう。実験中は 常時, 刺激の中央部左側, 刺激より $3 \mathrm{~mm}$ の距離江招い て直径 $2 \mathrm{~mm}$ の微弱な円形小光点を呈示して指 標之す る。被験者は顎支えで頭部を固定し， $1 \mathrm{~m}$ の観察距離か ら人工堙孔を通して右眼で観察する。刺激照度は 1f.cと し，被験者の眼から刺激呈示面までの間は遮光紙飞和拉 われて括り，暗順応15分後飞実験を開始するが，各条件 はランダムの順に実施す。

測定とは極限法を用いて，以下のような手順と判断基 準によつて 4 種の時間間隔を求めるが, 下降系列, 上昇 系列ともに 5 回実施す。下降系列：(1) 2 刺激間飞明瞭に 全視野が一たん暗黒となる印象* の生ずる 時間間隔から 始めて， $2 \mathrm{msec}$ の歩みでその㭙隔を短縮し，始めてこ の印象の消失する時間間隔。(2)さらに時隔を短縮し, 継 時 2 剌激が始めて別箇の 2 印象を生じなくなる時間間 隔。上昇系列 : (1) 完全に 1 印象の生ずる時隔より始めて

* 第 1 刺激図形の全体が完全に消失して, 一たん全 視野が暗黒となり，ついで第2刺激が出現する印象 を指す。 
$2 \mathrm{msec}$ の歩みで時隔を增し，始めて明らかと別箇の 2 印象の生ずる時間間隔。(2)さらに㭙隔を増大し，始めて 明らか江 2 刺激間に全視野の暗黒方認められる時隔。以 上の諸值のうち，下降系列(1)と上其系列(2)の备㭙隔の平 均値を分離間と呼び，これを $t_{s}$ で表わす。下降系列(2)と 上昇系列(1)の各時隔の平均值を融合閾と呼び，これを $\mathrm{t}_{f}$ で表わす。

被験者 東京教育大学心理学專攻学生.名。

Table 1 Mean thresholds of separation $\left(t_{s}\right)$ and fusion $\left(t_{\rho}\right)$ in $\mathrm{msec}$ as functions of stimulus area and stimulus duration

\begin{tabular}{c|r|r|r|r}
\hline $\begin{array}{c}\text { area } \\
\left(\mathrm{mm}^{2}\right)\end{array}$ & $\begin{array}{r}\text { exposure } \\
\text { time(msec) }\end{array}$ & 100 & 200 & 400 \\
\hline \multirow{2}{*}{$2.5^{2}$} & $\mathrm{t}_{s}$ & 274 & 244 & 208 \\
& $\mathrm{t}_{f}$ & 56 & 64 & 69 \\
$5^{2}$ & $\mathrm{t}_{s}$ & 210 & 202 & 179 \\
& $\mathrm{t}_{f}$ & 74 & 65 & 70 \\
$10^{2}$ & $\mathrm{t}_{s}$ & 219 & 209 & 181 \\
& $\mathrm{t}_{f}$ & 66 & 69 & 70 \\
$20^{2}$ & $\mathrm{t}_{s}$ & 217 & 201 & 176 \\
& $\mathrm{t}_{f}$ & 61 & 68 & 58 \\
$40^{2}$ & $\mathrm{t}_{s}$ & 317 & 328 & 263 \\
& $\mathrm{t}_{f}$ & 45 & 47 & 57
\end{tabular}

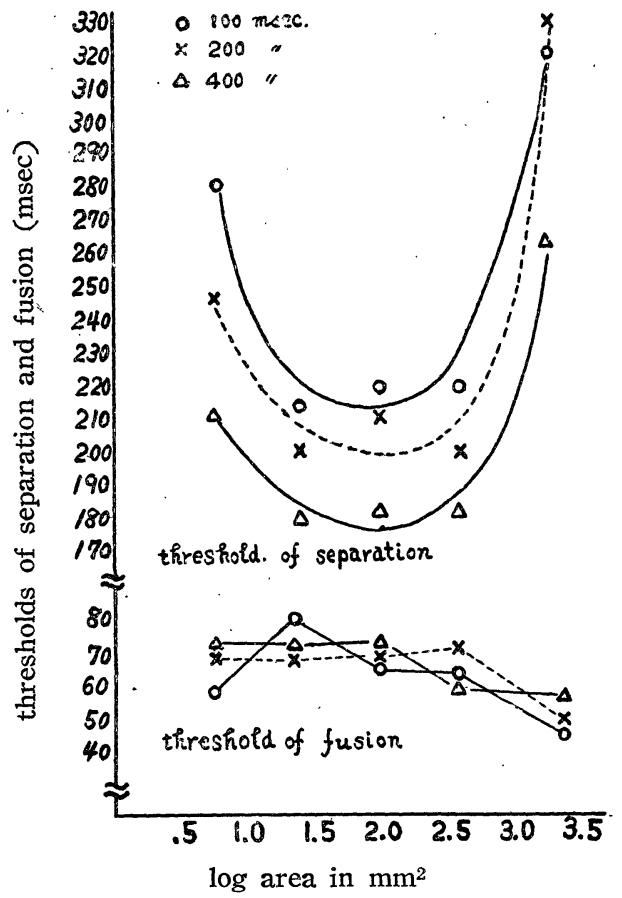

Fig. 1 Curves showing relations of thresholds of separation and fusion to stimulus area for various stimulus durations
実験期日 昭和28年4月から昭和29年 2 月まで。

結果 Table 1, Fig.1, Fig.2 のと掠り。Fig.1 の横 軸惊刺激面積 ( $\mathrm{mm}^{2}$ 単位) の対数を表わし，各カーブは 呈示時間別に画かれたものである。この結果は Fig.2の ようと表わすとともできる。 Fig.2 の橫軸は呈示時間 (msec単位) の対数を表わし, 各カーブは刺激面積別に 画かれたものである。

まず刺激面積と分離閾との関係を見ると Fig.1 の示す ように，分離閾は面積が小 $(\log$ area=0.8) であるとか なり大であるが，面積が増す $(\log$ area = 1.4) と減少す

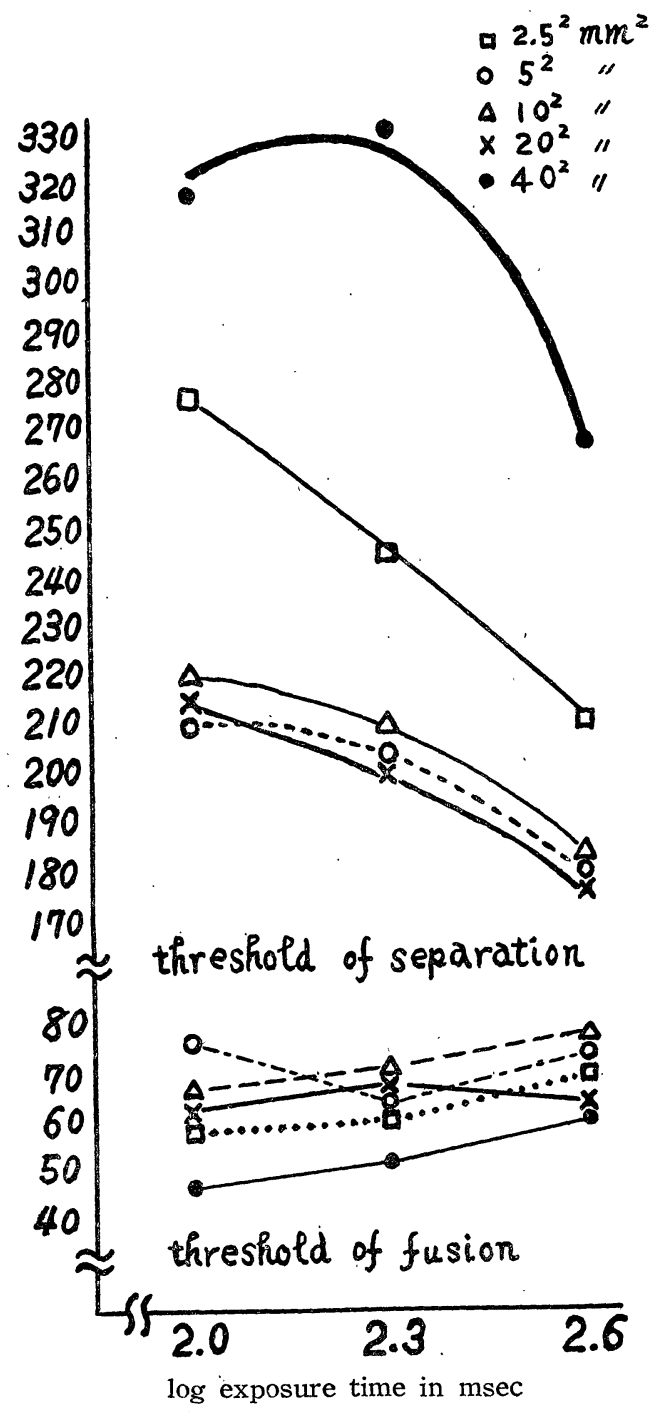

Fig. 2 Curves showing relations of thresholds of separation and fusion to stimulus duration for various stimulus areas 


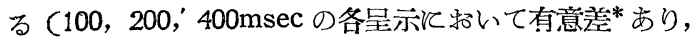
いずれも $\alpha<0.05)$ 。つでさらに面積が増しても, 一 定点までは閾値はさして変化しないが，その範井を超え てさらと面積が大 $(\log$ area $=3.3)$ となると，閯值は急

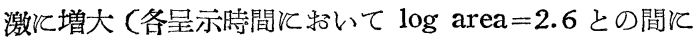
有意差あり, $\alpha<0.01$ または $\alpha<0.05)$ し, $\log$ area= 0.8 V和ける閾值を屯凌駕して (200, 400 msec の各呈示 、执いて有意差あり， $a<0.01$ ), 最大值《達している。 これらの傾问は，呈示時間の長さとかかわりなく認めら れ，各カーブは図のよう《扰物線型となる。

次融合䦭汇ついて述べると，分離間が大凡 180〜330 msecであるのと対して融合闇ははるか低く，大凡40〜 $70 \mathrm{msec}$ 前後の值となつている。Fig.1の各カーブは $\log$ area $=2.0$ 以上となると面積が増すとともと下降してい るといつてよい。また閾值は $\log$ area $=3.3$ 亿掓て最 低となつているため, 融合点から分離点任至る範囲, す なわち $\mathrm{t}_{s} \sim \mathrm{t}_{f}$ の值は最大面積机いて最大となつてい る。この事実は両䦭值のむつ意義を示唆するものであろ う。

以上の結果をさらと呈示時間との関係に扔いて 検討す るためと Fig. 2 とついて見る。分離閾を示す諸カーブは 刺激面積の大, 中 $\left(20^{2} \sim 5^{2} \mathrm{~mm}^{2}\right)$, 小の別によつて 3 種 と大別できるが，いずれも呈示時間の増大とより䦨值は 下降している**。他方, 融合閾㤬示特間飞よつて特定 の変化を示さない。

\section{考 察}

初めすず本実験と採用された判断基潐に関して述べ る。従来の時間閾の研究飞括いては，一般飞 2 刺激を継 時的江与て両者が始めて時間的炕前後して感じられる “時間間隔が測定されているが，視覚領域関しては研究 者によつて次のようなまちまちな值が報告されている。 刺激閾 值

Exner 電気火花 $44 \mathrm{msec}$ (観察距離 $28 \mathrm{~cm}$ )

Weyer (1) $12.1 \mathrm{msec}$

(1つには見えるが何となく2つであると認識でき る程度)

(2) $62.9 \mathrm{msec}$

(2つであるとは認識できるが，現象的には 1 つの 火花が顥動するように見光る程度)

* 表中の值についてではなく, 丁度可知の值につい でテストを怙こなつた結果で以下これね準ずる。

**次のよ弓飞各条件間に $\alpha<0.05$ で有意差あり。 $40^{2}$ $\mathrm{mm}^{2}: \log$ exposure time $=2.6 と 2.3,20^{2} \mathrm{~mm}^{2}$ 括よび $5^{2} \mathrm{~mm}^{2}: \log$ exposure time $=2.6$ と.3, $2.5^{2} \mathrm{~mm}^{2}: \log$ exposure time $=2.3$ と. 0
(3) $75.8 \mathrm{msec}$

(辛うじて分離して2印象と認識できる程度)

(4) $93.8 \mathrm{msec}$

(明らかと分離して2印象と感じられ，その間に持 続を認識できる程度)

Bassler 䐺黑の間隔 $40 \mathrm{msec}$

(文献 (2), (3), (4)による)

われわれは Weyer の諸基準と Schultze(5)の観察諸 現象とを参照し，種々な基準によつて子備実験を括こな つたが，その多くが観察の基準としては多義的で測定值 にも変動の著しいことを知つた。そこで諸基準中でも比 較的, 観察も容易で測定值の変動も少いものとして, 既 述の基淮を採用した。上記の㭙間間の研究については, まだ原論文によつて実験方法や条件の詳細を知る機会を えないが，一般に条件の嫢定が十分なものとはいい難い ように見受けられる。ゆえにこれらの結果を本結果と比 較対照して立入つた論考を進めるわけにはゆかないが， Weyer の(2) の測定は, 判断法を閾值の上から見て, 本 研究の融合間と近い。

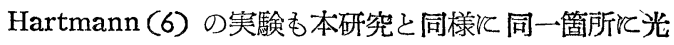
束激を2. 回是示して融合值を測つたものであるが，氏の 実験では呈示時間と休止時間が独立的でなく, 比例的衣 変化されて拉り, かつ融合值は円盤の迴転速度によつて 示されているため, 嚴密にいえば本研究と相違する。し かしながら氏の結果中，刺激の大きさの效果(6,346ff.) に関して, 本研究に準じて融合時の呈示時間と休止時間 を算出すると, 大きさの堌大とともそ休止時間は減少し て和り, 呈示㭙間が概胳 20〜30msec であると対して休 止時間は概略50〜70msec (ただし剌激は, 縦 $30 \mathrm{~mm}$, 巾 は0.3〜20mm間の， 7 種で $2.5 \times 10^{-4} \sim 42 \times 10^{-4} \mathrm{HK} / \mathrm{cm}^{2}$. 間の 5 段階, 中心視つとなり, 本結果の融合閾に近い。 以上のようと本結果中の融合閾值は, 類似した方法に よつてえられた值と類似している。Granit, Harper (7) のフリッカーの実験とよれば, 中心視に和いて, 視陆 $1^{\circ}$ $\sim 5^{\circ}$ の剌激に関しては $\mathrm{CFF}=\mathrm{c} \log \mathrm{A}+\mathrm{d}$ (ただし $\mathrm{A}$ は 面積, c, d 怯常数) の式が成立し, Kugelmass, Landis (8)の結果むこれの成立する場合のあることを示した。後 者の結果の 1 部(8, p. 13) そついて, 融合時の 1 サイクル 当りの, 刺激の与えられていない休止時間を算出すると 面積 $\left(\mathrm{mm}^{2}\right)$ の対数が約1.38〜3.5間の5 種の值と対して 休止時間は約 $46 \mathrm{msec} \sim 32 \mathrm{msec}$ (lightdark ratio $=0.5$ ) となり，面積の増加とともに休止時間はほ医線的に減 少している。もちろん, フッッカー法は刺激を反復呈示 している点や一般湜示時間と休止時間とが独立に変化 されていない点，ならびそ観察基淮や呈示時間などの諸 
点から本研究と相違するため, その測定値は本結果と異 なるが，Fig.1 の示すようと融合閾が面積の増大とより 減少する事実は, フリッカーの実験結果や Hartmann の 結果と一致している。

次分離間が一定限度玉では面積の增大とよつて下降 するという結果む上述の, Hartmann の結果, CFF 亿 関する結果と一致する。ところが面積が一層大となると 䦨值は大となつたが，これは暗順応眼が大きな光刺激に 回数を重社て曝されるため明順応状態樎つたためでは なからうかとも一応は考光られる。この想定が妥当であ るとするならば融合閾が，分離間測定の場合と同一面積 の大きな刺激炕よつて 分離閾とは逆浓小となる矛盾はい が説明さるべきであろうか。また Dunlap (2), Hartmann(6), Schaternikoff(9) の結果尤ね゙゙, 明順応飞 よつて融合は括とりにくくなつている。これらのことか ら, 分離間の増大を明順応效果汇帰することには 無理が あろう。

次残像の影響いかえについて考兄てみる。分離閾の 測定にあたつては，融合閾測定の場合よりも2 刺激間の 時隔が長いため，残像の出現が何らかの影響を和よぼす という可能性を一応想定できる。Feinbloom (10)は曋室 中で, 2400 f.c. の刺激份順応させた後 2000 f.c. の刺激 (視角 $1.5^{\circ}$ ) を呈示し, 晤黒中で後者の残像を単眼, 中 心視によつて観察させたところ, 後者の刺激の 50～1000 $\operatorname{msec}$ の 8 種の呈示㭙間以より残像の潜伏㭙は, 呈示時 間の增大とともに延長し，1.25 4.6sec の値となつた。 この条件は, 本実験条件と此較的近く, 本実験汸いて 屯第 2 刺激消失後に限つて時汶像出現の報告はあつた が，その潜伏時は少くも $1 \mathrm{sec}$ 以上であつた。しかも既 述のようと残像の消失特より少くも10sec を経てから次 の剌激呈示が括こなわれている。これら各種の事実から 考觉て，残像の影響が結果中に現われていないことがわ かる。

次㳊網膜の構造上から考光てみる。面積 $40^{2} \mathrm{~mm}^{2}$ が視 角約 $2^{\circ} 24^{\prime}$ であると対して $20^{2} \mathrm{~mm}^{2}$ 約 $1^{\circ} 10^{\prime}$ であるた め, 前者が $20^{2} \mathrm{~mm}^{2}$ 以下の剌激とは異つて $\operatorname{rod}$ 機能の働 く網朕部位にもやや投影される事実によつて $40^{2} \mathrm{~mm}^{2}$ V 杼いて分離閾上算が生じたのではなかろうか。とはい光 この場合融合閥が逆炕むし下降傾向を示す事実は, この見解にもとごを来す。両闇が別な現象による測定で あるため，別種の椂相を示すということも一応㛈古ら れるが，この当否を確言するとは，な和一層の攻究を要 するであろう。

次分離間と呈示時間の関係炕ついて考察する。本実 験法とフリッカー法は相違するとはい方，両者柱密接な
関連をすつ以上まず両結果を比較してみる。いまフリッ カー法汪よる Dunlap(2) の結果と Bartley(11) の結果 の一部を図示すると Fig.3がえられる。図中の呈示㭙間 と休止時間は, 融合晆の 1 サイクル当りの值で, Bartley

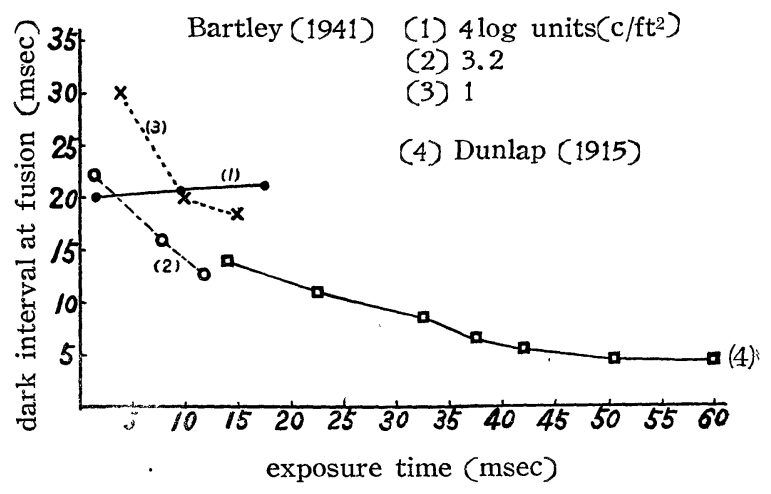

Fig. 3 Relation of dark time to light time at fusion for flicker experiments

の結果はわれわれが算出した概算值である。Fig.3 の示 すようと休止時間の值は，当然本結果と著しく相違する が，呈示時間の增大とともに休止時間は減少して扔り， 本結果と一致する。周知のようと呈示時間の効果は刺激 の強さや面積の効果と相互補償的な機能をるつ。本結果 そ颃いて呈示時間の増大とともに闇值は下降し, 小面積

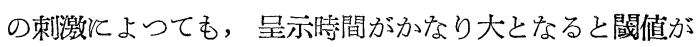
比較的小となる事実は，この従来の知見と一致するもの である。

以上， 2 刺激を同一部位飞与光る場合の 感賞融合飞つ いて述ベたが，次に 2 剌激を別な部位に与える場合にう いて述べる。

\section{2 刺激を別な箇所飞呈示するさいの 同時閾}

問題 2 つの光刺激を空間間隔を隔てて，継時的火呈 示する場合, 両者間の㭙間間隔が適当な大きさであれば 運動印象が秥こり，㭙隔がより小となると運動印象は特 こらず，同者は同時出現して見方る。Koffka(12)㤆 象運動を融合現象として报つているが，融合の名を冠す

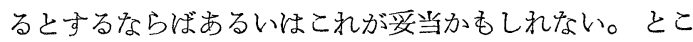
ろでわれわれは，刺激が同一部位江与兄られるとき亿両 者が㭙間的炕前後飞区別されず，1箇の印象となる時間 間隔を求めた。そこでわれわれは 2 刺激を別な籄所火与 光る場合，この融合閾值に対照すべき值を測定したいと 考光た。その試みとして以下述べるように，継時的な 2 束激芳㭙間的前後して見光ず，同時江知覚されるため 
の，両者間の最大封間間隔をその值として測定したが， これを同時閾と呼んで扮く。上記の目的からいえば，第

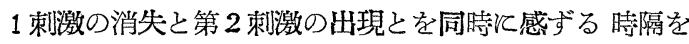
測定するのが至当と思われるが，この方法では観察がむ つかしく,さしあたつては, 両者の出現が同時感じら れる時隔を測定した。そのため刺激呈示時間は短くさ れ，同一部位汇呈示された場合と条件がかなり 相違する こととなつたが，ここではこの相違点にこだわることな く, 実駼結果を報告しておく。

\section{実 験 2}

目的 2 つの光刺激を継時的に別な場所呈示する 場合, 両者間の空間間隔の変化飞よつて, 同時䦭がい か飞変るかを明らかとする。

実験条件と実験方法 暗室中で 1 辺 $10 \mathrm{~mm} の, 2$ つ の正方形の光刺激を被験者の眼の高さで水平飞呈示 す。両者学隔てる空間距離は $1,2,5.3,10,15$, 22, 31.5, 40,50cmの9種とし, 2 刺激の呈示時間は ともと $20 \mathrm{msec}$ で，左の刺激を先炕呈示する。刺激の 点隇は TKK 式 (竹井製作所製) タキストスコープに より, 光源忙篮光燈を用う。実験中は 2 刺激間の中 央, 両者の底辺を結ぶ直線の $5 \mathrm{~mm}$ 下方に和いて，直 径 $3 \mathrm{~mm}$ の微弱な円形小光点を常時呈示して凝視点と す。被験者恃右眼で筒を通して観察するが，2剌激と 凝視点はそれぞれ右眼より $1.5 \mathrm{~m}$ の距離にある。実験 は暗順応15分後より開始し，2刺激の照度はとすに 1

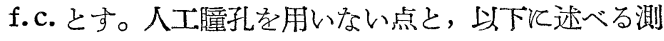
定手順とを除けば，その他の点は実験 1 と同様。湘定 は極限法により, 次の手順によつて下降系列, 上昇系 列と屯《 5 回実施す。下降系列飞扮いては，2剌激の 出現が明らかと継時的と把捉される㭙間間隔から始 め, $2 \mathrm{msec}$ の歩みで㭙隔を短縮し，始めて継時印象 の消失する時間間隔を求める。上抙系列飞称いては, 両者の出現が明らかに同時知覚される時隔から始めて $2 \mathrm{msec}$ の歩みで時隔を増大してゅき，始めて両者が明 らか継時的江出現する時隔を求める*。上上の10箇の值 の平均値をむつて同時間と定める。

被験者 東京教育大学心理学專攻者 4 名。

実験期日 昭和29年 $6 \sim 8$ 月

結果 被験者 4 名の平均值を Table 2 亿示す。

表のようと同時閾は, 刺激間の間隔とともと増大して いる。この事実は運動視の実験飞预いて, 空間間隔の増 大が同時時相の時隔範囲を大ならしめるという Neuhaus

*本実験抒よび以下の実験飞括いて, 運動印象の報 告は全くなかつた。
の結果(13) と一致するものである。いま縦軸同時間を とり，橫䡛に 2 刺激をはさむ視㑇*をとつてプロットす

Table 2 Mean threshold of simultaneity in msec. as a function of spatial distance between two stimuli

\begin{tabular}{c|c|c|c|c|c|c|c|c}
\hline 1 & 2 & 5.3 & 10 & 15 & 22 & 31.5 & 40 & 50 \\
\hline $\begin{array}{c}12 \\
\mathrm{msec}\end{array}$ & 16 & 22 & 27 & 35 & 41 & 44 & 51 & 55 \\
\hline
\end{tabular}

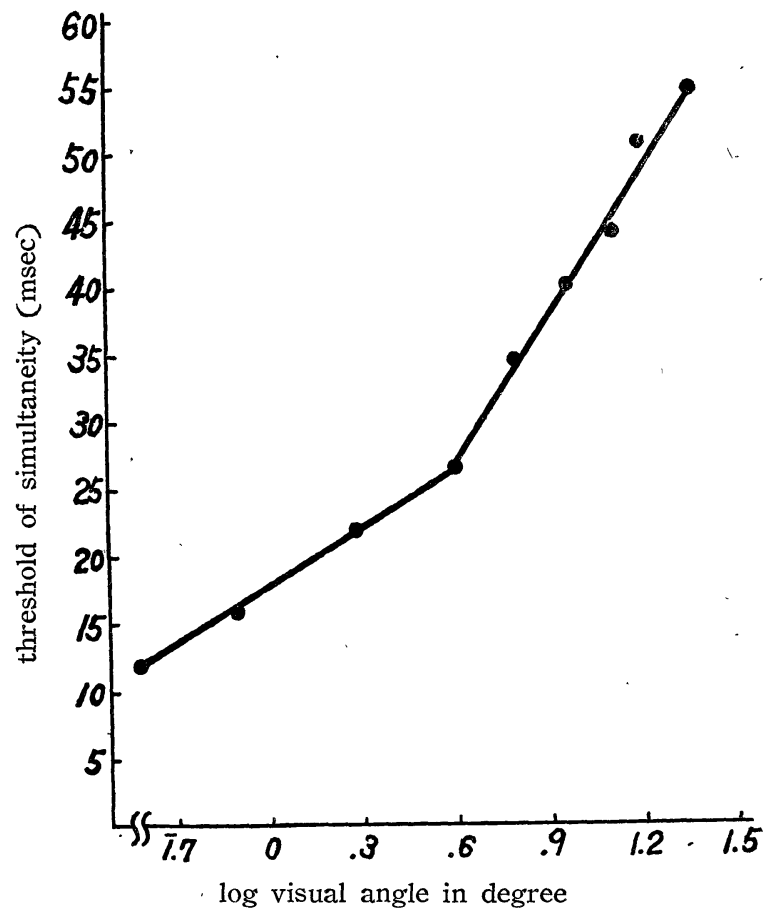

Fig. 4 Relation of threshold of simultaneity to visual angle between two stimuli. The lines are fitted by the method of least squares

ると Fig.4がえられる。圀中の 2 直線は, 最小自乗法の 適用によつてえられたもので，困のように同時䦨は視角 の対数に比例して増大し, 両者間に

$$
\mathrm{t}_{s i}=\mathrm{a}+\mathrm{k} \log \alpha
$$

の式が成立つ。ただし $t_{s i}$ は同時䦨， $\alpha$ は視角， a, k は 常数とす。常数 $\mathrm{a}, \mathrm{k}$ の值としては, 下部の回帰線に稿い ては9.68, 32.73 ( $\log \alpha$ と tsi との相関壮 $\gamma=0.999)$, 上部の回渟線には $17.75,15.0(\gamma=0.961)$ が与它られ る。

ところでこの場合, 刺激間の視角の増大, すなわち網 膜上の刺激像の間隔の増大は，同時に 2 刺激の客観的空，

* 左刺激の右端と右刺激の左端を挾む角を指す。 
間間隔挌よびみ壳の間隔の増大を伴つている。ゆ觉にこ の結果加ら同時䦨の増大が，視角の増大によつてのみ拉 こつたことを結論するわけにはゆかない。とこでつぎに は上記三種の間隔が平行的に変化しない事態に和いて 検 討してみる。

\section{実 験 3}

目的 視角，みえの間隔拉よび 絧膜像を一定に保ちつ つ, 客観的間隔を変化することとよつて 同㭙閥はいかな る值となるか原みる。

方法 $2^{\circ}, 12^{\circ}$ の 2 種の視角汇ついて実験す。被験者 の右眼から刺激までと凝視点までの距離は相等しく，

$2.25 \mathrm{~m}, 3 \mathrm{~m}$ の 2 種とす。これと比例して刺激の大き さは，とれぞれ $15^{2}, 20^{2} \mathrm{~mm}^{2}$ とするが，これ応じて凝 視点の大きさも比例的に変化する。このようにして網膜 像の大きさは一定値を保たれる。また刺激間の客観的間 隔も観察距離と比例的飞变化することによつて 2 刺激間 の視角を一定滘ち，刺激照度は 1 f.c. 亿保つ。実験は 暗室中で筒を通して単眼視によつておこなわれるため大 きさの恒常現象はほとんどおこらず，刺激間の客観的間 隔の変化的かかわらずみ党の間隔はほぼ一定を保つ。 その他の点は実験 2 と同様。

結果 Table 3 中の括弧で囲まれない数值。此較の便 宜上 実験 2 の結果中本実験と同一視角でえられたものも Table 3中に揭げて挍いた。表の示すように，各視角下

Table 3 Thresholds of simultaneity in msec. as a function of a visual angle between two stimuli

\begin{tabular}{|c|c|c|c|c|c|c|}
\hline $\begin{array}{l}\text { visual } \\
\text { angle }\end{array}$ & \multicolumn{3}{|c|}{$2^{\circ}$} & \multicolumn{3}{|c|}{$12^{\circ}$} \\
\hline $\begin{array}{l}\text { distance } \\
\text { between } \\
\text { stimuli }\end{array}$ & $5.3 \mathrm{~cm}$ & $7.9 \mathrm{~cm}$ & $\begin{array}{r}10.5 \\
\mathrm{~cm}\end{array}$ & 31.5 & 47.3 & 63.0 \\
\hline $\begin{array}{c}\begin{array}{c}\text { observing } \\
\text { distance }\end{array} \\
\mathrm{O}_{s}\end{array}$ & $150 \mathrm{~cm}$ & $225 \mathrm{~cm}$ & $300 \mathrm{~cm}$ & 150 & 225 & 300 \\
\hline$T$ & $\begin{array}{c}27 \\
(20)^{*}\end{array}$ & $\begin{array}{c}28 \\
(30)\end{array}$ & $\begin{array}{c}28 \\
(29)\end{array}$ & $\begin{array}{c}40 \\
(31)\end{array}$ & $\begin{array}{c}38 \\
(31)\end{array}$ & $\begin{array}{c}37 \\
(25)\end{array}$ \\
\hline $\mathrm{Y}$ & $\begin{array}{c}18 \\
(20)\end{array}$ & $\begin{array}{c}19 \\
(20)\end{array}$ & $\begin{array}{c}19 \\
(26)\end{array}$ & $\begin{array}{c}49 \\
(31)\end{array}$ & $\begin{array}{c}49 \\
(40)\end{array}$ & $\begin{array}{c}49 \\
(38)\end{array}$ \\
\hline $\mathrm{H}$ & $\begin{array}{c}20 \\
(21)\end{array}$ & $\begin{array}{c}20 \\
(24)\end{array}$ & $\begin{array}{c}20 \\
(27)\end{array}$ & $\begin{array}{c}44 \\
(26)\end{array}$ & $\begin{array}{c}43 \\
(35)\end{array}$ & $\begin{array}{c}43 \\
(37)\end{array}$ \\
\hline $\mathrm{K}$ & $\begin{array}{c}24 \\
(28)\end{array}$ & $\begin{array}{c}26 \\
(28)\end{array}$ & $\begin{array}{c}25 \\
(22)\end{array}$ & $\begin{array}{c}44 \\
(29)\end{array}$ & $\begin{array}{c}45 \\
(30)\end{array}$ & $\begin{array}{c}43 \\
(20)\end{array}$ \\
\hline Av. & $\begin{array}{c}22 \\
(22)\end{array}$ & $\begin{array}{c}23 \\
(26)\end{array}$ & $\begin{array}{c}23 \\
(26)\end{array}$ & $\begin{array}{c}44 \\
(30)\end{array}$ & $\begin{array}{c}44 \\
(34)\end{array}$ & $\begin{array}{c}43 \\
(30)\end{array}$ \\
\hline
\end{tabular}

* The value put in brackets indicates the result for a light room.
そ和いて同特䦨はそれぞれ一定值を保つ。また視㑇 $12^{\circ}$ と抒いて閾值がより大きい（同一観察距離相互間にそれ ぞれ $a<0.01$ で有意差あり)ことは実験 2 の結果を再確 認したものである。以上のことから視角，見壳の間隔， 括よび網膜像が一定であると同時閾は，客観的間隔と観 察距離の変化と無関係に一定值を保つことがわかつた。 しかしながら実験 2，3飞拈いては視角と見党の間隔と が平行関係をもつて变化しているため, 両実験の結果か らはその両要因が，それぞれどの程度に同時閾值を涣定 する上の役割を果しているかが明らかでない。つぎにこ の点について検討する。

\section{実 験 4}

目的視角を一定保ち，見光の間隔を変化すること によつて同時閾がいかに変化するかをみる。

方法 明室中で突験す。2 刺激間の中央上方と，被験 者の頭上約 $1 \mathrm{~m} \mathrm{~V} 6 \mathrm{~V}$ の豆電球を 1 箅ずつ点燈する。そ の他の点は実験 3 と同様。本実験では視质之網膜像は一 定に保たれているが，恒常現象が和こるため客観的間隔 が増す（観察距離の増大を伴う）とともに見えの間隔は 増大する。

結果 Table 3 中の括弧内の值。表の示すようと, 視 角が一定でも見えの間隔が増すと閾值の增大傾向を示す 被験者と，然らざる被験者とがあり，結果は判然としな い。な招, 視角 $12^{\circ}$ のさいに明室実験に招いて暗室実験 よりも閾值は小となつている（各間隔に抒いて有意差あ り， $\alpha<0.001$ または $\alpha<0.05)$ こが注目される。

\section{考 察}

IとII の実験は条件がかなり相違するため，両者の結 果を仔細に比較対照することはできない。しかしながら 前後の 2 刺激が空間的飞接近して与只られるときには, 両者が同時的に知覚される最大時間間隔は，同一籄所に 与えられる場合に比して 急激汇減少するものとみなして 誤りはなかろう。すなわち, 後呈示される刺激が前呈示 される刺激と別な部位に与えられるならば，前者後者 の残効果を直接的には蒙らないため，同一部位に与えら れる場合のような融合現象は掠こらず，加えて束激位置 の相違も識別されるため 同時閾は小となるのであろう。

次に Fig. 3 亿示した視角之同時閾との関係についてや や述べる。Polyak (14) とよれば絧膜，中心窝の視角 $1^{\circ} 40^{\prime} \sim 2^{\circ}$ の領域は, さら飞視角 $5^{\circ}$ 飞まで就よぶ cone の優越領域汇よつて囲まれている。Fig.3 の直線の勾配 は, 視角 $4^{\circ}$ 以下では $6^{\circ}$ 以上飞和けるより䌅くなつて いるが，これはこうした網膜構造上の特性汇基くのであ 
ろう。ただしこのことがみえの間隔の影響を否定するこ ととならないことはいうまでもない。小笠原の実験(15) そよれば, $\beta$ 運動は刺激の網膜上の間隔よりもみえの間 隔によつて規定され，同様なととは時程の比較と疑いて も認められている(16)。矢田部(17) 毛先後弁別閾関し てこの問題いかんを提起しているが，同時知覚関して の本研究も, 実験がまだ不十分であるため問題を换起し

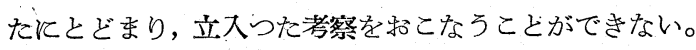
な招，同時閾が明室より瞕空実験と招いてより大となつ たことは，好適運動が叔こるための休止時間が，暗室に 抒いて明室よりも大となつた小笠原の結果(15) と軌を一 にしている。これて関してもいまは間題を提起するとと ぞめて抹く。

\section{III 要 約}

本研究は， 2 つ光刺激を継時的飞同一部位、等時間 呈示することとょつて融合現象を攻究した。前刺激が消 失して全視野が一たん暗黒となつてのち 後刺激が再び見 えるための, 両者間の最小㭙間間隔を分離間と呼び, 両 者によつて 1 箇の印象のみが生ずる最大時間間隔を融合 閾と呼び, この 2 種の閾值が, 刺激の面積と呈示特間飞 よつていか、変わるかを測定した。実験結果の大要を列 挙すれば次のと拉りである。

1. 分離間以面積の増大林小となるが，ついで 一定点まで注面積の増大にもかかわらずほぼ一定值を保 つ。面積がさらと大となると閾值は上昇に転じ，この経 過は扰物線型となる。

2. 分離間は, 呈示時間の增大によつて小となる。

3. 融合閾以分離間飞比べるとはるか、小さい。融合 閾は面積の増大によつて小となるが，呈示特間の変化に より特定の変化を示さない。

4. 2 刺激を空間間隔を隔て，㠜視点を挾えで対称の 位置飞継時的飞皇示する場合, 上記融合閾に対応するも のとして, 両者の出現が同時に知覚される最大時間間隔 (同時䦭と呼ぶ)をとり, その值を測定した。その結果 飞よれば，(a）2刺激間の視角とみえの間隔の両者がと むと小である場合，同時闇は融合閾よりあ小となるもの と思われる。(b) 同時閥は，2剌激間の視角とみえの間 隔の両者が相伴つて增すにつれて大となり，その增大の 仕方は視角の対数江此例する。（c） 2 刺激間の視角とみ えの間隔を一定に保つと, 両者間の客観的空間間隔と観 察距離を変化しても同封閾は一定値を保つ。

\section{附 記}

本研究中の I 、, 交部省科学研究費 (昭和28年度, 小 保内担当) そよる研究である。その大要は, 交部省科学 研究費和よび科学研究助成費による各個研究招よび助成 研究報告集録一哲, 史, 交学編 (昭和29年 4 月末現在) 報告されている。

\section{交 献}

1) 水沢清江: 時間知営装置, 心理学研究, 20 No. 4, 1950, 18-22.

2) Dunlap, K. : The shortest perceptible timeinterval between two flashes of light. Psychol, Rev. 22, 1915, 226 250.

3) 安部三郎”：時間意識の心理, 昭和12年

4) 高木・城戸監修 : 実験心理学提要, 第2巻, 1952.

5) Schultze, F.E.C. : Beiträge zur Psychologie des Zeitbewusstseins. Arch.f.d.ges. Psychol. 13, 1908, 275 351.

6) Hartmann, L. : Beiträge zur Psychologie der Gestalt VIII. Neue Verschmelzungsprobleme. Psychol.Forsch. 3, 1923, 319 396.

7) Granit, R. and Harper, P. : Comparative studies on the peripheral and central retina: $\mathbb{I}$ Synaptic reaction in the eye, Amer. J.Physiol. 95, 1930, 211 228.

8) Kugelmass, S. and Landis, C. : The relation of area and illuminance to the threshold for critical flicker fusion, Amer.J.P sychol. 63, 1955, 1 19.

9) Schaternikoff, M. : Über den Einfluss der Adaptation auf die Erscheinung des Flimmerns, Zeitschr. f. Psychol. 29, 1902, 241 254.

10) Feinbloom, W: : A quantitative study of the visual after image, Arch.Psychol. 33, 1938, No. 233.

11) Bartley, H.S. : Vision, 1941, p.121.

12) Koffka, K. : Principles of Gestalt Psychology, 1935, 285ff.

13) Neuhaus, W. : Experimentelle Untersuchung der Scheinbewegung, Arch.f.d.ges.Psychol. 75, 1931, 315 458.

14) Polyak, S.L. : The Retina 1941.

$15 ＼mathrm{~ 小 笠 原 慈 瑛: ~} \beta$ 運動に文ぼす現象的間隔の影響 心理学研究, 11, 1936, 109 122.

16) 須藤泰男 : 現象的距離の時間知覚飞及ぼす影響 心理学研究, 16, 1941, 95 115.

17) 天野利武：比輍の心理, 昭和24年, p.337. - 1956.2.14. 受稿 一 